\title{
XINYU Zhang
}

\section{„Pannig er saga okkar"61}

\section{Um sagnritunarsjálfsögur og skáldsöguna Hundadaga eftir Einar Má Guðmundsson}

Nei, hér parf engu að ljúga. Рað er engin skylda að ljúga í skáldsögum. Hér fær veruleikinn vængi og flýgur um heiminn. ${ }^{2}$

Pannig lætur Einar Már Guðmundsson sögumanninn komast að orði í skáldsögu sinni Hundadögum (2015). Мeð pessum orðum afhjúpar sögumaðurinn „mótsagnakenndan“ hugsunarhátt sinn; hann fullyrðir að hann hafi lítinn sem engan áhuga á að ljúga í pessu skáldverki par eð um „raunverulegar persónur á leiksviði sögunnar“ (206) sé að ræða. Í verkinu stíga svo sannarlega margvíslegar sögulegar persónur frá ólíkum tímum og löndum fram á frásagnarsviðið og flakka jafnvel fram og aftur í tíma og rúmi. Meðal annars er sagt frá séra Jóni Steingrímssyni eldklerki, fornfræðingnum seinheppna Finni Magnússyni, hundadagakónginum Jörgen Jörgensen og hundadagadrottningunni Guðrúnu Einarsdóttur Johnsen. En pó að sögumaður bendi á að pað sé „engin skylda að ljúga í skáldsögum“ veit hann einnig að hann er að semja skáldsögu. Skáldskap (e. fiction) og veruleika, eða nánar tiltekið

1 Grein pessi er að hluta til unnin upp úr BA-ritgerð minni í íslensku sem öðru máli við Háskóla Íslands og fyrirlestri sem ég flutti á ráðstefnunni Hrunið, pið munið við Háskóla Íslands 6. maí 2018. Ég stend í mikilli pakkarskuld við Jón Karl Helgason, leiðbeinanda minn við ritgerðina, Bergljótu S. Kristjánsdóttur, Eirík S. Ólafsson, Rannveigu Sverrisdóttur og ónafngreinda ritrýna fyrir góðar hugmyndir, ábendingar og yfirlestur.

2 Einar Már Guðmundsson, Hundadagar, Reykjavík: Mál og menning, 2015, bls. 25. Hér eftir verður vitnað til pessa verks með blaðsíðutali innan sviga í meginmáli.

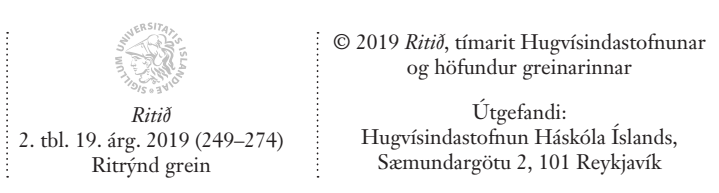

Birtist á vefnum http://www.ritid.hi.is. Tengiliður: ritið@hi.is

DOI: $10.33112 /$ ritid.19.2.10

Birt samkvæmt skilmálum

Creative Commons BY (4.0). 
skáldskap og sögu (e. history), ${ }^{3}$ lýstur ítrekað saman í Hundadögum með fullri sjálfsvitund (e. self-consciousness) sögumannsins, en pað sama má segja um allmargar aðrar skáldsögur sem kenndar eru við póstmódernisma.

Í pessari grein verða Hundadagar greindir ítarlega í ljósi framangreinds einkennis póstmódernískra skáldsagna, en pó einkum með hliðsjón af hugtakinu sagnritunarsjálfsaga (e. historiographic metafiction) sem kanadíski bókmenntafræðingurinn Linda Hutcheon skilgreindi með athyglisverðum hætti í bók sinni A Poetics of Postmodernism: History, Theory, Fiction (1988). ${ }^{4}$ Par færir hún rök fyrir kenningum sínum um póstmódernisma og útfærslu hans í skáldskap með pví að greina allmarga bókmenntatexta, einkum af vettvangi enskra bókmennta frá síðari helmingi 20. aldar. Sömu einkenni eða bókmenntastrauma má finna víðar um heim og Ísland er par engin undantekning. Pó hefur hugtakið sjaldan borið á góma hér á landi og pví verður sjónum fyrst beint að kenningum Hutcheon um póstmódernisma og póstmódernískan skáldskap áður en fjallað verður um skáldsöguna Hundadaga.

\section{Póstmódernismi og sagnritunarsjálfsaga}

Kenningar Hutcheon um sagnritunarsjálfsögur byggja á bókmenntahugtakinu sjálfsaga (e. metafiction) sem einkennt hefur umræðu um módernískar og póstmódernískar bókmenntir á liðnum áratugum, en samkvæmt skilgreiningu Hutcheon eru sagnritunarsjálfsögur skáldsögur „sem eru sjálfslýsandi, en leggja hald sitt á sögulega atburði og persónur á pverstæðukenndan hátt“. 5 Einhver frægustu dæmi um pær í heimsbókmenntum eru, samkvæmt henni, Hundrað ára einsemd (1967) eftir Gabríel García Márquez, Astkona franska lautinantsins (1969) eftir John Fowles, Mið̌neturbörn (1981)

\footnotetext{
Íslenska orðið saga er margrætt og kann að merkja 1. „frásögn“, 2. „atburðarás sem síðar er sagt frá, e-ð sem gerist“, 3. „mannkynssaga, frásögn af próun einstakra pátta eða greina“, 4. „sagnfræði“, 5. „sagnfræðirit“, 6. „sögugyðjan, sagan persónugerð“, 7. „skáldsaga“, sjá Íslensk orðabók, 5. útg., ritstj. Mörður Árnason, Reykjavík: Forlagið, 2010, bls. 817-818. Síðar í pessari grein verður greinarmunur gerður á sagnfræði (e. history), sagnritun (e. historiography) og sögu (e. history) í merkingunni „e-ð sem gerist".

4 Linda Hutcheon, A Poetics of Postmodernism: History, Theory, Fiction, London og New York: Routledge, 1988.

5 Sama rit, bls. 5. Á ensku segir, „[novels] which are both intensely self-reflexive and yet paradoxically also lay claim to historical events and personages“. Ég vil pakka Bergljótu Soffíu Kristjánsdóttur fyrir býðinguna á hugtakinu sem hún benti á í námskeiðinu „Glæpasagan“ við Háskóla Íslands á vormisseri 2017.
} 
eftir Salman Rushdie og Páfagaukur Flauberts (1984) eftir Julian Barnes, ${ }^{6}$ par sem saga, kenningar og skáldskapur fléttast einatt saman.

Раð kenningalíkan sem Hutcheon hefur próað byggir fyrst og fremst á póstmódernískri byggingarlist, par sem hún kemur auga á áhugavert samspil fortíðar og nútímans, meira að segja nútímalegan áhuga á fortíðinni í formi paródíu, ${ }^{7}$ en líkanið á einnig rætur í ýmsum póstmódernískum bókmennta-, heimspeki- og sagnfræðikenningum. Deilt hefur verið um tungumálið, eðli pess og hvernig pví er beitt, en pað varðar einmitt samband sögu og skáldskapar, enda varðveitist söguleg pekking okkar hvað mest í rituðum frásögnum, ${ }^{8}$ og ýmsir hafa leitt að pví rök að bæði saga og skáldskapur séu hugarsmíð manna.

Á sjöunda og áttunda áratugnum urðu páttaskil innan sagnfræðinnar, skil sem sneru bæði að máli og frásögn (e. narrative/linguistic turn). Sagnfræðingurinn Hayden White, sem hefur að ýmsu leyti átt stóran pátt í að móta pau, gerir greinarmun á sögulegum atburðum og birtingarmyndum peirra í frásagnarformi. Рað sem sagnfræðingar gera með söguritun sinni er ekki að framkalla hinn sögulega raunveruleika, heldur að sverfa og smíða frásagnir af honum og út frá honum sjálfum. Мeð öðrum orðum, enda pótt hinn sögulegi raunveruleiki sé svo sannarlega til, geta menn einungis komið til móts við hann óbeint, í gegnum einhvern miðil, sem er oftar en ekki söguritun sagnfræðinga. Kjarni málsins er pví hvernig sagnfræðingar búa til skipulagða sögu (e. story) úr óreiðukenndum atburðum (e. event). ${ }^{9}$ White gerir meðal annars ráð fyrir sagnasmíð/fléttusmíð (e. emplotment) sem vinnubrögðum

6 Sama rit, t.d. bls. 5 og 44. Skáldsaga Barnes Flaubert's Parrot hefur ekki komið út á íslensku, en Árni Sigurjónsson hefur pýtt brot úr henni sem birtist í Tímariti Máls og menningar 2/1996, bls. 100-106. Sjá líka langan verkalista í Amy Elias, „Historiographic metafiction“, The Cambridge History of Postmodern Literature, ritstj. Brian McHale og Len Platt, New York: Cambridge University Press, 2016, bls. 293-307, hér bls. 293-295, par sem D. M. Thomas, J. M. Coetzee, Toni Morrison og margir fleiri koma við sögu.

7 Sjá t.d. Linda Hutcheon, A Poetics of Postmodernism, bls. 22-36; The Politics of Postmodernism, 2. útg., London og New York: Routledge, 2002, bls. 11-13.

8 Tekið skal fram að sögulega pekkingin er auðvitað líka varðveitt annars staðar en í frásögninni einni, til að mynda í ljósmyndum, myndböndum og hljóðböndum, en pessar efnislegu birtingarmyndir sögunnar eru langt frá pví að geta kallast „hlutlægar“, enda er peim alltaf miðlað í gegnum pann aðila sem heita má böfundur, og eru pess vegna alltaf litaðar túlkun hans.

9 Hayden White, „The Historical Text as Literary Artifact“, Tropics of Discourse: Essays in Cultural Criticism, Baltimore og London: The Johns Hopkins University Press, 1978, bls. 81-100. 
sagnfræðinga, en slíkar smíðar einkenna sömuleiðis skáldskapinn, par sem höfundur (og oftlega sögumaður) vinnur með heimildir og býr til sögur upp úr peim. ${ }^{10}$ Með líkum hætti og íslenska orðið saga nær yfir bæði margskonar skáldaðar frásagnir og sagnfræðilegt efni, telur White sagnfræðilegan texta vera að einhverju leyti bókmenntalegan tilbúning (e. literary artifact), enda deila skáldskapur og sagnfræðirit oftlega sama frásagnarmynstri.

Sagnfræði White er pannig meta-sagnfræði, pví hann dregur athygli manna að athöfn og afurð sagnfræðinnar. Í pví sambandi má nefna að hugtakið bistoriographic metafiction hefur einnig verið pýtt á íslensku sem „sagnfræðileg metaskáldverk“, ${ }^{11}$ en með pýðingunni „sagnritunarsjálfsaga“ er undirstrikað að um er að ræða sagnritun (e. historiography), ${ }^{12}$ pann texta sem fær mann til að íhuga ýmis atriði sem hafa áhrif á birtingarmyndir sögunnar, til dæmis hvað sagnfræðingar hafa kosið að segja frá og hverju peir hafa sleppt eða paggað niður, og hvernig sagnfræðingar hafa komist að mismunandi reyndum (e. fact) um sömu sögulega atburði (e. event). ${ }^{13}$ Pannig er hin „hlutlæga“ sagnfræði afbyggð vegna pess að hún birtist fyrst og fremst sem frásagnarverk og er pví mjög háð vali, túlkun og hugmyndafræði pess sem ritar verkið og par með er litið svo á að ekki sé hægt að endurheimta fortíðina með neinum afdráttarlausum og hlutlægum hætti.

En petta pýðir pó ekki að fortíðin eða sagan sé ekki til. Hutcheon segir um petta atriði: „Ekki er litið svo á að saga sé úrelt: hún er aftur á móti endurskoðuð - sem hugarsmíð mannsins. [...] aðgangur okkar að henni er nú algjörlega háður textum. Við getum ekki pekkt fortíðina nema í gegnum textana sem henni tilheyra [...]“. ${ }^{14}$ Petta er sannarlega mótsagnakenndur hugsunarháttur: söguleg pekking er dregin í efa um leið og hún er stað-

10 Sjá líka Monika Fludernik, „Experience, Experientiality, and Historical Narrative: A View from Narratology", Erfahrung und Geschichte: Historische Sinnbildung im Pränarrativen, ritstj. Thiemo Breyer og Daniel Creutz, Berlín og New York: De Gruyter, 2010, bls. 40-72, hér bls. 40-42.

11 Gunnpórunn Guðmundsdóttir, „Skáldað um líf: Sjálfsævisögur sem bókmenntagrein á tímum póstmódernisma“, Skírnir 177: vor/2003, bls. 109-125, hér bls. 117.

12 Sjá Frank Ankersmit, „Historiography“, Routledge Encyclopedia of Narrative Theory, ritstj. David Herman, Manfred Jahn og Marie-Laure Ryan, London og New York: Routledge, 2005, bls. 217-221.

13 Sjá t.d. Linda Hutcheon, A Poetics of Postmodernism, bls. 153. Á ensku segir, „History offers facts - interpreted, signifying, discursive, textualized - made from brute events.“ „Reyndir“ (e.fact) eru merkingarbær túlkun á „atburðum“ (e. event).

14 Linda Hutcheon, A Poetics of Postmodernism, bls. 16. Á ensku segir, „History is not made obsolete: it is, however, being rethought - as a human construct. [...] its accessibility to us now is entirely conditioned by textuality. We cannot know the past except through its text [...]." 
fest, en póstmódernismi, samkvæmt skilgreiningu hennar, er einmitt fyrst og fremst „mótsagnakenndur, eindregið sögulegur og óhjákvæmilega pólitískur“. ${ }^{15}$ Póstmódernismi bæði „notar og misnotar, setur fram og grefur síðar undan peim hugmyndum sem hann vefengir“, hann bendir á að margt af pví sem við teljum vera náttúruleg fyrirbæri sé í raun og veru menningarleg hugarsmíð. ${ }^{16}$ Póstmódernismi gagnrýnir par með hugmyndafræði sem hann tekur pátt í sjálfur, hann einkennist pví bæði af gagnrýni (e. critique) og pátttöku (e. complicity). Póstmódernismi er samkvæmt pessu alltaf beði/og, aldrei annaðhvort/eða.

En um hvaða póstmódernisma er að ræða? Tekið skal fram að Hutcheon lítur á póstmódernisma fyrst og fremst sem menningarstarfsemi, ${ }^{17}$ á meðan aðrir líta á hann sem pekkingarfræðilegt og félagsmenningarlegt/félagshagfræðilegt fyrirbæri eða ástand, en raunin er pó sú að petta prennt spilar einatt saman. ${ }^{18}$ Fredric Jameson aðhyllist síðastnefndu skoðunina og lítur á póstmódernisma sem „menningarlega rökvísi síðkapítalismans“. Á meðan umfjöllun um afstöðu til fortíðar og sögu er lykilatriði bæði hjá Jameson og Hutcheon, telur Jameson að póstmódernismi einkennist meðal annars af flatneskju (e. flatness), dýptarleysi (e. depthlessness), dofnandi hrifum eða kenndum (e. waning of affect) gagnvart sögunni, svo ekki sé talað um að hann sé daufdumbur (e. deafness) andspænis henni. Jameson gagnrýnir í stystu máli póstmódernisma fyrir áhugaleysi og afskiptaleysi gagnvart pólitík og sögu. ${ }^{19}$ En á peim tímum sem kenndir eru við póstmódernisma eygir Hutc-

15 Sama rit, bls. 4. Á ensku segir „fundamentally contradictory, resolutely historical, and inescapably political“.

16 Sama rit, bls. 3. Á ensku segir, ,uses and abuses, installs and then subverts, the very concepts it challenges“. Sjá líka Linda Hutcheon, The Politics of Postmodernism, bls. 2. Ástráður Eysteinsson hefur drepið á kenningar Hutcheon um póstmódernisma í grein sinni „Hvað er póstmódernismi?“, Umbrot: Bókmenntir og nútimi, Reykjavík: Háskólaútgáfan, 1999, bls. 369-401, hér bls. 384.

17 Linda Hutcheon, A Poetics of Postmodernism, bls. 23-28.

18 Sjá Amy Elias, Sublime Desire: History and Post-1960s Fiction, Baltimore og London: The Johns Hopkins University Press, 2001, bls. xx-xxvii. Sjá líka Nico Baumbach, Damon R. Young og Genevive Yue, „Revisiting Postmodernism: An Interview with Fredric Jameson“, Social Text 2/2016, bls. 143-160, hér bls. 143-144. Jameson vill nú gera greinarmun á milli póstmódernisma-skeiðs (p.e. sögulegs tímabils, e. postmodernity) og póstmódernisma-stíls (p.e. fagurfræðilegs stíls, e. postmodernism).

19 Fredric Jameson, „Póstmódernismi eða menningarleg rökvísi síðkapítalismans“, pýð. Magnús Pór Snæbjörnsson, Af marxisma, ritstj. Magnús Pór Snæbjörnsson og Viðar Porsteinsson, Reykjavík: Róttæka sumarútgáfan, 2012, bls. 236-301, hér bls. 243, 246-247; Postmodernism, or, The Cultural Logic of Late Capitalism, London og New York: Verso, 1991, bls. xi. 
heon aftur á móti gríðarlegan og raunverulegan áhuga, í byggingarlist og bókmenntum til að mynda, á sögu og pólitík, og ólíkt Jameson, kýs hún enn fremur að undirstrika virkni menningarinnar andspænis félagshagfræðilegum aðstæðum, en sú virkni felst einkum í svonefndri „gagnrýni í gegnum pátttöku“ (e. complicitous critique). ${ }^{20}$

Höfuðaðferðir slíkrar gagnrýni innan frá eru paródía og írónía, ${ }^{21}$ en að mati Jamesons er paródía á póstmódernískum tímum reyndar „verkefnalaus" (e. without a vocation) og hið einkennilega fyrirbæri pastís (eftirlíking eða stæling) hefur komið í hennar stað.22 Hann telur að póstmódernismi einkennist af merkingarlausri neyslu fremur en framleiðslu, hlutlausri pátttöku fremur en gagnrýni, pví að póstmódernismi geti ekki framleitt neitt nýtt, heldur leiki hann sér einungis með brot úr fortíðinni og sé á pá lund flæktur í eins konar nostalgíu. Hutcheon lítur málin öðrum augum; hún telur að paródía sé enn jákvætt og skapandi afl. Paródía, skrifar hún, er „endurtekning úr gagnrýnni fjarlægð sem birtir írónískan mismun í innsta kjarna líkinda““. ${ }^{23}$ Hún afhjúpar einmitt eina helstu mótsögn póstmódernismans, pví að hún hefur tvöfalda merkingu, getur bæði vísað til pess sem er andstætt og hliðstætt tilteknu viðfangsefni. Paródía er með öðrum orðum tvöföld í roðinu; hún bæði viðurkennir og véfengir, löggildir og kollvarpar pví sem hún beinist að. Petta er pað sem Hutcheon kallar tvöfalda kóðun (e. double encoding): „Póstmódernísk paródía er bæði gagnrýnin á afbyggjandi hátt og

20 Linda Hutcheon, The Politics of Postmodernism, bls. 23. Sjá líka Jón Yngvi Jóhannsson, „Upphaf íslensks póstmódernisma: Um fyrstu ljóðabækur Einars Más Guðmundssonar", Kynlegir kvistir tíndir til beiðurs Dagnýju Kristjánsdóttur fimmtugri, ritstj. Soffía Auður Birgisdóttir, Reykjavík: Uglur og ormar, 1999, bls. 125-142, hér bls. 125 .

21 Hutcheon hefur fjallað ítarlega um paródíu og íróníu í A Theory of Parody: The Teachings of Twentieth-Century Art Forms, Urbana og Chicago: University of Illinois Press, 1985 og Irony's Edge: The Theory and Politics of Irony, London og New York: Routledge, 1995. Bergljót Soffía Kristjánsdóttir hefur fjallað um íslensk bókmenntaverk með hliðsjón af kenningum Hutcheon um íróníu og paródíu, sjá „,,... hvers leitar skiftíngur pinn í rassgörn pesssari? “: Fáeinar athugasemdir um skáld, skáldskap, háð og spé í Gerplu“, Heimur skáldsögunnar, ritstj. Ástráđur Eysteinsson, Reykjavík: Bókmenntafræðistofnun Háskóla Íslands, 2001, bls. 80-92; „„,rjómaskán ofan í mitti“: Um „Sólstafi“ Lindu Vilhjálmsdóttur“, Heimur ljóðsins, ritstj. Ástráđur Eysteinsson, Dagný Kristjánsdóttir og Sveinn Yngvi Egilsson, Reykjavík: Bókmenntafræðistofnun Háskóla Íslands, 2005, bls. 66-79.

22 Fredric Jameson, „Póstmódernismi eða menningarleg rökvísi síðkapítalismans“, bls. 256.

23 Linda Hutcheon, A Poetics of Postmodernism, bls. 26. Á ensku segir, „repetition with critical distance that allows ironic signalling of difference at the very heart of similarity“. 
skapandi á uppbyggilegan hátt, hún dregur fram pverstæður og vekur athygli okkar á takmörkum jafnt sem áhrifum framsetningar - í hvaða miðli

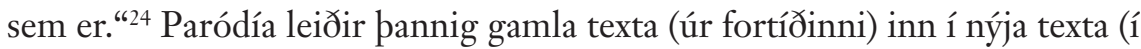
nútíðinni); hún gerir okkur kleift að skrifa um fortíð í nútíð, og í pví skammhlaupi felst ekki „nostalgísk endurkoma“, heldur „gagnrýnin endurskoðun og írónísk samræða við sögu“ listarinnar og samfélagsin ${ }^{25}$ - endurskoðun sem felur í senn í sér framsetningu á sögunni og afbyggingu sögunnar.

Öll pessi einkenni póstmódernismans eru sömuleiðis einkenni sagnritunarsjálfsagna, enda eru pær að viti Hutcheon helsta (og í rauninni eina) birtingarmynd póstmódernisma í skáldskap. Petta eru skáldsögur sem einkennast af mikilli sjálfsvitund og kalla má sjálfsögur - pær eru skáldsögur um skáldsögur par sem athygli er vakin á að skáldskapur sé tilbúningur (e. artifact), „1́ peim tilgangi að vekja upp spurningar um samband skáldskapar og veruleika“. ${ }^{26}$ Sjálfsögur eru meðvitaðar um möguleika sína og takmörk sem ráðast af pví að pær eru skáldskapur og hugarsmíð tiltekins höfundar, og í ofanálag bundnar máli og felldar í frásögn; pær draga með öðrum orðum ekki dul á pekkingu sína á pví hvað veldur möguleikunum og takmörkunum sem peim eru sett. ${ }^{27}$ Sjálfsögur pykjast ekki vera að skírskota til empírísks veruleika utan skáldskapar, heldur eru pær sjálfsvísandi. Pess vegna eru sagnritunarsjálfsögur „mótsagnakenndari og sögulega flóknari“28

24 Linda Hutcheon, The Politics of Postmodernism, bls. 94. Á ensku segir, „Postmodern parody is both deconstructively critical and constructively creative, paradoxically making us aware of both the limits and the powers of representation - in any medium".

25 Linda Hutcheon, A Poetics of Postmodernism, bls. 4. Á ensku segir, „not a nostalgic return; [it is] a critical revisiting, an ironic dialogue with the past."

26 Patricia Waugh, Metafiction: The Theory and Practice of Self-Conscious Fiction, New York og London: Methuen, 1984, bls. 2. Pýðingin er fengin af vefsíðu Jóns Karls Helgasonar, en par er að finna gagnlegan lista yfir ýmis hugtök sem tengjast sjálfsögum, sjá http://uni.hi.is/jkh/kennsla/hugtok/.

27 Um hugtakið metafiction sjá m.a. Patricia Waugh, Metafiction; Linda Hutcheon, Narcissistic Narrative: The Metafictional Paradox, New York og London: Methuen, 1984; Brian McHale, Postmodernist Fiction, London og New York: Routledge, 1987. Ýmsir íslenskir fræðimenn hafa líka gert tilraunir til að kynna hugtakið metafiction og pýða pað yfir á íslensku, sjá einkum Jón Karl Helgason, „Deiligaldur Elíasar: Tilraun um frásagnarspegla og sjálfgetinn skáldskap“, Ritið 3/2006, bls. 101-130; „Tólf persónur leita höfundar: Tilraun um sögusagnir og dæmisagnalist“, Skírnir 182: vor/2008, bls. 81-120; „„Pú talar eins og bók, drengur“: Tilraun um meðvitaðan skáldskap“, Skirnir 185: vor/2011, bls. 89-122.

28 Linda Hutcheon, A Poetics of Postmodernism, bls. 40. Á ensku segir, „more paradoxical and historically complex". 
en aðrar sjálfsögur - pær segja frá pví sem hefur gerst í formi skáldskapar; pær látast í upphafi vera að skírskota til empírísks veruleika eins og tíðkast í raunsæisskáldskap og hefðbundnum sagnfræðiritum, en efast einnig mjög um milliliðalaust samband textans og veruleikans. Sagnritunarsjálfsögur spretta meðal annars upp fyrir margvísleg áhrif frá kenningum eins og nýsöguhyggju og póststrúktúralisma par sem litið er á sagnfræðirit sem bókmenntalegan tilbúning, en pær eru ekki síður andsvör skáldsagnahöfunda við félagslegum veruleika, svo sem styrjöldum, nýlendufrelsun, kynpátta-, kvenna- og hinsegin hreyfingum - andsvör til að umskrifa og jafnvel breyta hinni skráðu og alhæfðu sögu. Framsetning á sögunni og skirskotun til hennar eru pannig í raun grunduð í sagnritunarsjálfsögum. ${ }^{29}$

Рað er pessi hrifning á sögunni sem greinir sagnritunarsjálfsögur og sjálfsögur að. Hutcheon telur pví að sjálfsögur eins og bandaríska ofur-skáldsagan (e. surfiction) og franskan nýsagan eða ný-nýsagan (e. New Novel, New New Novel) séu ekki póstmódernískar heldur módernískar, og sagnritunarsjálfsagan sýni öðrum formum betur hversu mótsagnakenndur póstmódernisminn er. ${ }^{30}$ Bandaríski bókmenntafræðingurinn Brian McHale heldur pví fram að módernískar bókmenntir spyrji pekkingarfræðilegra spurninga um heiminn (Hvernig get ég túlkað heiminn sem ég er hluti af og hvað er ég í honum?) á meðan póstmódernískar bókmenntir spyrji verufræðilegra spurninga (Hvaða heimur er petta, hvað á að gera í honum og hvaða sjálf mitt á að gera pað?). ${ }^{31}$ Sagnritunarsjálfsögur spyrja, samkvæmt skilgreiningu Hutcheon, bæði pekkingarfræðilegra og verufræðilegra spurninga: „Hvernig getum við pekkt fortíðina (eða nútíðina)? Hver er verufræðileg staða peirrar fortíðar? Heimildanna um hana? Frásagna okkar? “32 Pannig

29 Sjá Amy Elias, „Historiographic Metafiction“, bls. 293-295, 301. Sjá líka Monika Fludernik, „History and Metafiction: Experientiality, Causality, and Myth“, Historiographic Metafiction in Modern American and Canadian Literature, ritstj. Bernd Engler, Schöningh: Paderborn, 1994, bls. 81-101, hér bls. 84.

30 Linda Hutcheon, A Poetics of Postmodernism, bls. 40 og 108. Amy J. Elias skiptir hins vegar póstmódernískum bandarískum skáldsögum í prennt: 1) sjálfsögur sem endurspegla póststrúktúralískar kenningar um tungumál og einbeita sér mjög að forminu, 2) sagnritunarsjálfsögur, 3) skáldsögur par sem nýttar eru sjálfsögulegar aðferðir en eru samt frábrugðnar áðurnefndu tveimur gerðunum. Sjá „Postmodern metafiction“, The Cambridge Companion to American Fiction after 1945, ritstj. John N. Duvall, New York: Cambridge University Press, 2012, bls. 15-29, hér bls. 17-18. Frekari gagnrýni á hina pröngu skilgreiningu og flokkun Hutcheon á póstmódernískum skáldskap má finna síðar í pessari grein.

31 Brian McHale, Postmodernist Fiction, bls. 9-10.

32 Linda Hutcheon, A Poetics of Postmodernism, bls. 50. Á ensku segir, „How do we 
taka sagnritunarsjálfsögur virkan pátt í umræðunni um sögulega pekkingu og gera pá jafnan hvort tveggja í senn að draga pekkingu okkar í efa og sýna okkur fram á hve margbrotin hún sé: Er fortíðin í okkar augum „,raunveruleiki“ (e. reality) eða fyrst og fremst pað sem við höfum aðgang að í gegnum texta eða heimildir (e. textualized accessibility) ${ }^{33}$ Sagnritunarsjálfsögur afhjúpa einmitt pessa mótsögn.

\section{Sjálfsagan Hundadagar}

Nú er tímabært að beina sjónum að skáldsögunni Hundadögum og kanna hvernig hugtakið sagnritunarsjálfsaga getur nýst til greiningar á henni. Skáldsagan kom út á Íslandi og í Danmörku á sama tíma árið 2015 og hlaut Íslensku bókmenntaverðlaunin sama ár. Hundadagar er „söguleg skáldsaga“ en líka „túlkun á samtíma““, ${ }^{4}$ eða segjum nútímaleg söguleg skáldsaga par sem fléttað er saman práðum úr sögu Íslands og mannkynssögunni pannig að frásögnin teygir sig yfir nokkrar aldir, meira að segja frá 18. öld til 21. aldar.

Ólíkt pví sem tíðkast í skáldsögum Walters Scott, „föður“ bókmenntagreinarinnar söguleg skáldsaga eða söguleg rómansa, fjallar skáldsaga Einars Más um raunverulegar sögulegar persónur, eins og albekkt er í mörgum sagnritunarsjálfsögum. ${ }^{35}$ Par er sérstaklega sagt frá ævi danska „lukkuriddarans"Jörgens Jörgensen (1780-1841), sem sigldi um höfin blá, gerði byltingu á Íslandi og varð kóngur par í tvo mánuði árið 1809, en var sendur aftur til Tasmaníu sem fangi eftir að bylting hans misheppnaðist, og dó par. Samhliða frásögninni af Jörgen er sagt frá ævi séra Jóns Steingrímssonar (17281791) sem var vottur að Skaftáreldunum árið 1783 og var talinn hafa stöðvað eldhraunið með messu sinni. Báðir voru peir kumpánar flæktir í ýmis ástaog peningamál og par að auki ritaði séra Jón, eins og Jörgen, ævisögu til að hreinsa mannorð sitt. ${ }^{36}$ Finnur Magnússon (1781-1847) fornfræðingur er

know the past (or the present)? What is the ontological status of that past? Of its documents? Of our narratives?"

33 Sjá sama rit, bls. 114.

34 Ásdís Sigmundsdóttir, „Brúarsmiður eða farartálmi“, Fréttablaðið 4. desember 2015, bls. 30 .

35 Um petta einkenni sagnritunarsjálfsagna sjá Linda Hutcheon, A Poetics of Postmodernism, bls. 114-115.

36 Um ævisögu séra Jóns sjá Matthías V. Sæmundsson, „Upplýsingaröld 1750-1840“, Íslensk bókmenntasaga III, ritstj. Halldór Guðmundsson, Reykjavík: Mál og menning, 1996, bls. 23-217, hér bls. 124-134. 
gerður að tengiliðarpersónu séra Jóns og Jörgens í lok skáldsögunnar (sbr. 340-341) auk pess sem ævi og fræðistörf hans eru einnig rakin. Hundadagadrottningin Guðrún Einarsdóttir Johnsen (1790-1860) er líka pess háttar persóna; lesandinn kynnist ævi hennar en hún tengir jafnframt saman sögur af Jörgen og Finni (sbr. 337-341). Síðast en ekki síst er sögumaður í Hundadögum býsna fyrirferðarmikill og gegnir reyndar bæði hlutverki sögumanns og sögupersónu ${ }^{37}$ eins og sýnt verður hér á eftir; hann hefur sögulega yfirsýn og næmt auga fyrir samtímanum - meðal annars hruninu 2008 og stöðu Íslands í heiminum.

Byrjað skal á pví að kanna sögumanninn í Hundadögum, sem einkennist af sterkri sjálfsvitund og fer ekki í launkofa með sköpunarferli sitt, rétt eins og venjan er með sögumenn í sjálfsögum. ${ }^{38}$ Hann segir til að byrja með frá í fyrstu persónu fleirtölu, „við“, eins og sjá má í eftirfarandi dæmum úr fyrsta kaflanum í fyrsta hluta skáldsögunnar:

Við köllum hann Jörund hundadagakonung enda er hann á sinn hátt eini kóngurinn sem við höfum átt. (9)

Petta sést best á pví að við munum varla hvað hinir raunverulegu kóngar hétu og pví síður drottningar peirra, nema pær allra kræfustu. [...] Að öðru leyti vorum við lítið að spá í petta fólk. [...] Í stuttu máli sagt, við höfum ekki mikið af pessum kóngum að segja.

37 Ýmsir ritdómarar hafa fjallað um hinn fyrirferðarmikla sögumann Hundadaga, sjá t.d. Ásdís Sigmundsdóttir, „Brúarsmiður eða farartálmi“ og Steinunn Inga Ottarsdóttir, „Napóleón norðursins: Um Íslands eina kóng“, Kvennablaðið.is, 15. nóvember 2015, sótt 17. febrúar 2019 af https://kvennabladid.is/2015/11/15/napoleon-nordursins-um-islands-eina-kong/. Ásdís vill jafnvel meina að sögumaður sé „aðalpersóna bókarinnar en ekki Jörundur eða aðrar persónur“.

${ }^{38}$ Jón Karl Helgason bendir á að í alpjóðlegri umræðu séu til tvenns konar hugtök sem hefjst á meta- eða self-, en pau ganga að vissu leyti aftur á íslensku: „Pekktustu hugtökin í fyrri hópnum eru meta-bókmennntir (fr. méta-littérature) [...] og metaskáldskapur (e. metafiction) [...]. Í síðarnefnda flokknum eru meðal annars hugtökin sjálfsmeðvituð skáldsaga (e. self-conscious novel) [...] og sjálfbverf frásögn (e. narcissistic narrative)“, sjá „Deiligaldur Elíasar“, bls. 102-104. Meta-bókmenntir og metaskáldskapur eru nefnilega bókmenntir um bókmenntir, í peim er að finna yfirvegun og umfjöllun bókmennta um tilveru sína, en eins og fram hefur komið í nmgr. 27 hafa sjalfsmeðvitaðar skáldsögur og sjálfbverfar frásagnir einnig verið kallaðar metafiction (sbr. Waugh og Hutcheon), enda eiga pær og meta-bókmenntir pað sameiginlegt að einkennast af sjálfsvitund um sköpunarferli skáldsögunnar, hvort sem skáldskapareðli hennar (e. fictionality) er gert sýnilegt eða ekki. 
Í sama kafla bregður pó einnig fyrir fyrstu persónu eintölu frásögn: „Ég ætla ekki að dæma um pað hér og nú en spyr: Hver var Jörgen Jörgensen, hvað gerðist og hvers vegna? Ég vona að við fáum svör við pessum spurningum, og raunar fleirum, áour en sögu lýkur" (11).

Síðar í skáldsögunni kemur í ljós að pegar sögumaður fjallar um frásagnarathöfn sína (fr. narration, e. narrating) ${ }^{39}$ pá skýtur fyrsta persóna eintölu, „ég", oft upp kolli:

Petta hljómar eins og í minningargrein en ég er ekki að skrifa minningargrein. [...] Ég gæti líka sagt: Pað er nótt [...]. Ég ætti að segja hábjartur dagur [...]. (21)

Рað gerðist margt par á milli, skal ég segja ykkur, og ég er ekkert endilega að segja pessa sögu í réttri röð, af pví að í rauninni er ekkert til sem heitir rétt röð og petta er ekki saga um menn sem gengu í réttri röð. (44)

Раð er nefnilega dálítið merkilegt að pegar ég segi að hér sé allt satt og að hér purfi engu að ljúga, pá er lygin oftar en ekki pað sem sannleikurinn snýst um, viðfangsefni hans, enda sannleikurinn lyginni líkastur eins og pið hafið eflaust rekið ykkur á í pessari sögu og lífinu sjálfu. (150)

39 Hér er stuðst við prískiptingu Gérards Genette. Frásögnin skiptist í sögupráð (fr. bistoire, e. story), frásagnarorðræðu (fr. récit, e. narrative) og frásagnarathöfn. Sögupráđur er inntak frásagnarinnar, frásagnarorðræða er frásagnartextinn sjálfur, frásagnarathöfn er ferlið eða athöfnin par sem frásagnarorðræðan verður til, sjá Narrative Discourse: An Essay in Method, pýð. Jane E. Lewin, Ithaca og N.Y.: Cornell University Press, 1980, bls. 27. Venjulega er ekki nauðsynlegt að greina frásagnarorðræðu og frásagnarathöfn í sundur, pví að lesendur komast aðeins í tæri við frásagnarorðræðuna, og athöfnin eða ferlið par sem hún verður til skiptir litlu máli fyrir frásögnina. En mörg dæmi sýna greinilega að fyrstu persónu sögumaðurinn „ég“ i Hundadögum gerir frásagnarathöfnina sýnilega eins og oft er gert í sjálfsögum. Rétt er að taka fram hér að pessi frásagnarathöfn er reyndar hluti af sögupræðinum, pví skáldsagan Hundadagar fæst umframt allt við að skrá niður sögur persóna. 
Með pessum metafrásagnarlegu athugasemdum (e. metanarrative comment) ${ }^{40}$ dregur sögumaður athygli lesenda frá sögupræðinum að sjálfri tilveru hans og frásagnarathöfn hans. Fyrstu-persónu-eintölu-sögumaður ávarpar einnig lesendur beint eins og oft er gert í sjálfsmeðvituðum skáldsögum, ${ }^{41}$ og hann talar í anda munnlegrar frásagnar fremur en fræðilegs stofnanastíls: „Já, hlustið nú!“ (51 og 313); „Eins og pið heyrið pá get ég ekki alveg sagt skilið við séra Jón. Sögur eru aldrei búnar pó að peim ljúki [...]“ (238).

Vert er bó að nefna að sögumaður í Hundadögum fæst meðal annars við að skrá niður sögur peirra Jörgens, séra Jóns og fleiri persóna upp úr heimildum. ${ }^{42}$ Petta minnir á aðferð sagnfræðinga við söguritun - peir fletta líka upp í ýmsum heimildum eins og sögumaður gerir, en peir afhjúpa pá aðferð frekar lítið opinberlega og fela sig gjarnan á bak við priðju-persónu-frásagnarrödd og skrifa í fræðilegum stíl. En pegar sögumaður Hundadaga finnur til að mynda frásagnir um afstöðu móður Jörgens til sonar síns í sjálfsævisögu H. C. Andersens og endursegir pær með sínum eigin orðum, pá segir hann í framhaldinu: „Við missum af frekari sögum af peim málum pví að strax á eftir er H. C. Andersen farinn að tala um sjálfan sig og hvað móður Jörgens pótti hann efni í gott skáld“ (54).

Með slíkum metafrásögnum tjáir fyrstu-persónu-sögumaður Hundadaga opinberlega pau takmörk sem blasa við honum í heimildavinnu og minnir á

40 Hugtakið metanarration eða metanarrative felst í pví að sögumaður fjallar opinskátt um frásagnarorðræðu eða frásagnarathöfn sína, en greinarmunur verður gerður á metafiction og metanarration, pví að fyrrnefnda hugtakið snýst meira um hið skáldaða eða hugsmíðaða eðli frásagnarorðræðunnar og sögumannsins - en petta tvennt getur auðvitað unnið saman. Sjá Ansgar Nünning, „On Metanarrative: Towards a Definition, a Typology and an Outline of the Functions of Metanarrative Commentary", The Dynamics of Narrative Form: Studies in Anglo-American Narratology, ritstj. John Pier, Berlín og New York: Walter de Gruyter, 2004, bls. 11-57.

41 Brian Stonehill, The Self-Conscious Novel: Artifice in Fiction from foyce to Pynchon, Pennsylvania: University of Pennsylvania Press, 1988, bls. 30, sjá Jón Karl Helgason, „Pú talar eins og bók, drengur“, bls. 102. Hér má líka nefna að Einar Már Guðmundsson lætur sögumann oft tala beint til lesenda í verkum sínum, t.d. strax í sinni fyrstu skáldsögu Riddurum bringstigans, Reykjavík: Mál og menning, 1999 [1982], bls. 19: „Pú hlýtur að skilja mig, lesandi góður, pegar ég byrja að pæla í pví hvernig ég geti klekkt á afmælisbarninu." Einskonar munnleg samræðukennd verður pannig til.

42 Sjá t.d. síðustu setninguna í síðasta kafla skáldsögunnar: „Nú sér hann [Finnur Magnússon] aftur móta fyrir prestinum, séra Jóni Steingrímssyni, sem stuttu síðar kom gangandi með kraftaverk á herðunum, kraftaverk sem enginn sá af pví að pannig er saga okkar, kraftaverk sem enginn sér“ (341) - enginn hefur séð pau kraftaverk, en pau eru skráð í heimildum. Рað sem Einar Már Guðmundsson lætur sögumann sinn gera er einmitt að segja frá peim upp úr ýmsum heimildum. 
hversu persónubundnar sögulegar heimildir eru. Pess vegna leyfir hann sér líka að láta huglægni sína leika lausum hala: „Pegar Jörundur hélt dansleiki gættu lífverðirnir dyranna og var Jens [íslenskur strákur] á meðal peirra pó að ekki finni ég hann í skránni yfir lífverðina sem er líklega af pví að nafni hans hefur verið breytt í heimild minni“ (197). Slík meðferð á heimildum er í anda svonefndrar „apókrýfrar sögu“ (e. apocryphal history) eða „póstmódernískrar endurskoðandi sögulegrar skáldsögu“ (e. postmodernist revisionist historical novel), par sem endurskoðaðar og endurtúlkaðar eru sögulegar heimildir sem og hefðbundin viðmið í sögulegum skáldskap, með pví að bæta ýmist við pví sem hefur glatast eða verið paggað niður í sögulegum heimildum ellegar leysir hina opinberu sögu af hólmi. ${ }^{43}$

Á stöku stað sýnir sögumaður líka að hann getur paggað niður í vissum röddum fortíðarinnar, eins og sagnfræðingar geta og hafa gert: ${ }^{44}$ „Evisagan og Eldritið, pað eru aðalbækurnar eftir séra Jón. Við styðjumst við pær en sneiðum hjá ýmsu sem ekki skiptir máli í okkar sögu og bætum við öðru sem kemur annars staðar að og lögum að okkar sögu“ (23). Valdabarátta um hina gildu og viðurkenndu orðræðu, p.e. bvaða og bvers sögur eru sagðar, ${ }^{45}$ birtist einnig í skáldsögunni pegar bylting Jörgens misheppnast og hann er kærður af ýmsu fólki. Bretinn Alexander Jones, skipstjóri á Talbot, sem handtekur Jörgen læur marga skrifa skýrslur til að skýra frá byltingunni, en „einn var sá sem Alexander Jones vildi ekki fá neina skýrslu frá. Рað var Jörgen Jörgensen“ (209), segir sögumaður, en „Jörgen Jörgensen átti líka eftir að hrekja orð skipstjórans lið fyrir lið í bók sinni“ (213). Pví má segja að frásagnaraðferðin í Hundadögum sé í vissum skilningi eftirlíking, afhjúpun og paródía á pví ferli sem býr að baki ritun sagnfræðilegra heimilda og rita, sem séu í eðli sínu menningarleg hugarsmíð og hugmyndafræðileg sköpun - líkt og skáldskapur.

Ávörpin og metafrásagnirnar trufla hið slétta og fellda frásagnarflæði og gera lesendur meðvitaðri um að peir eru að hlusta á sögu sem sögumaðurinn segir og mótar, svo að ónefnt sé að skáldsagan einkennist af samskipan eða hliðskipan (e. parataxis), ${ }^{46}$ p.e.a.s. að sögur af persónum frá ólíkum tíma og rúmi séu klipptar út, límdar saman og settar saman inn í sama rými á afar frjálsan hátt af sögumanni. Pessar frásagnaraðferðir raska hinum línulega orsakaskilningi á sögu og afhjúpa jafnframt hið hugsmíðaða eðli frásagnar

43 Brian McHale, Postmodernist Fiction, bls. 90.

44 Sjá Linda Hutcheon, A Poetics of Postmodernism, bls. 107.

45 Sama rit, bls. 123.

46 Sjá Amy Elias, Sublime Desire, bls. 122-136. 
sögumanns. Hér má einnig minnast á tvö helstu einkenni sagnritunarsjálfsagna, p.e. margföld sjónarhorn á sögu og sögumann sem stýrir frásögn á afar opinskáan hátt og setur pannig huglægan skilning sinn á sögu í forgrunn. ${ }^{47}$

Á bak við „við“-sögumannsröddina er pá „ég“-sögumaður sem breytir um fornafn og par með tilvísun. „Við“-frásagnir eru einskonar orðræðuaðferð ${ }^{48}$ sem „ég“"sögumaður beitir til að vekja tilfinningar og geðshræringar hjá lesendum; sögumaðurinn verður par með blendingur af sögumanni og áheyranda eða lesanda (við = ég + aðrir). Pó að lesendahópurinn sé víðar en á Íslandi, vísar „við“ i fyrrnefndum dæmum í rauninni einungis til sögumannsins og annarra Íslendinga, ${ }^{49}$ og hann notar „við“ til að ávarpa pá, flækja pá inn í frásögnina, vekja athygli peirra á frásögninni og tengja pá jafnframt við pann sögulega tíma sem skáldsagan lýsir.

Frásögnin er ýmist í pátíð eða nútíð; sögutíminn er stundum tíðin pegar Jörundur og aðrir kóngar voru uppi, stundum sá nútími sem við lifum í. Einn ritdómari Hundadaga segir um petta atriði: „Höfundur talar nefnilega um okkur; okkur sem lifum núna og okkur sem lifðum pá. Við erum til á tvennum tímum. " ${ }^{50}$ Í nútíðarfrásögnum eru lesendur samferða sögumanni sem grefur upp sögur af Jörgen, séra Jóni, Finni og fleiri og segir frá peim, en í pátíðarfrásögnum eru peir beinlínis gerðir pátttakendur í Íslands- og mannkynssögunni eins og sögumaðurinn sjálfur, sem er orðið ljóst í eftirfarandi dæmi: „Kannski brugðumst við líka kónginum, verndara vorum og hæstráðanda til sjós og lands. [...] Kom okkur petta brambolt eitthvað við? Hvenær höfðum við verið spurð: Styður pú byltinguna? Nei, við höfðum ekki verið spurð að neinu í svo margar aldir að við skildum ekki spurninguna“ (213). Með pví að tala um „okkur“ í pátíð, tengir sögumaðurinn sjálfan sig og lesendur við byltingu Jörgens - „við“ verðum með öðrum orðum Ís-

Linda Hutcheon, A Poetics of Postmodernism, bls. 117.

48 Munur er gerður á „við“-frásagnarorðræðu og „við“-frásagnarathöfn - hið fyrrnefnda vísar til peirra frásagna par sem fyrstu-persónu-eintölu-sögumaður situr við stýri á bak við fyrstu-persónu-fleirtölu-fornafnið, en hið síðarnefnda vísar til frásagna par sem merki „ég“-sögumannsins er hvergi að finna og „,við“-sögumaður sem einkennist af samhuglægni stýrir frásögninni. Sjá Natalya Bekhta, „We-Narratives: The Distinctiveness of Collective Narration“, Narrative 2/2017, bls. 164-181, hér bls. 168-172. Í grein Bekhtu má líka lesa um helstu frásagnarfræðilegar rannsóknir um „við“-frásagnir.

49 Í tilviki erlendra lesenda gerir sögumaður ráð fyrir að peir setji sig í spor Íslendinga.

50 Ingvi Pór Kormáksson, „Í heimsreisu með Jörundi“, Bókmenntaborgin.is, 2015, sótt 17. febrúar 2019 af http://bokmenntaborgin.is/umfjollun/hundadagar. 
lendingar á peim tíma sem bylting Jörgens var gerð. Pá má segja að notkun persónunafnsins „við“ tengi lesendur ekki aðeins við skáldsöguna, heldur einnig söguna - en eins og hér hefur komið fram pá minnir sögumaður stöðugt á riteðli (skáld)sögunnar.

\section{Sagnritunarsjálfsagan Hundadagar}

Segja má að Hundadagar séu bæði söguleg skáldsaga og ævisaga peirra sögulegu persóna sem eru par í fyrirrúmi. Einar Már Guðmundsson lýsti sjálfur skáldsögu sinni svo pegar hann tók við Íslensku bókmenntaverðlaununum fyrir hana: „Hundadagar eru skáldsaga, að nokkru leyti heimildaskáldsaga par sem heimildir eru notaðar á afar frjálslegan hátt. ${ }^{\text {"51 }}$ Hann styðst ekki aðeins við fræðileg sagnfræðileg rit, heldur líka sjálfsævisögur, skáldsögur og leikrit. Á síðustu blaðsíðunni í kiljuútgáfu Hundadaga má finna viðauka par sem Einar Már fjallar um pær heimildir sem hann notar:

Aðalheimildir sögunnar eru sjálfsævisögur aðalpersónanna, [...] síðan ótal aðrar heimildir sem sumar eru nefndar í sögunni en aðrar ekki. Af peim sem ekki eru nefndar í sögunni eru fjölmargar greinar Önnu Agnarsdóttur um Jörund hundadagakonung og samskipti Englands og Íslands, Eldhuginn eftir Ragnar Arnalds, Mannkynssaga 1789-1848 eftir Jón Guðnason, The Age of Revolution eftir Eric Hobsbawm, Vi, Förgen Förgensen eftir Claus Ib Olsen, Fribytteren eftir Kurt Frederiksen og leikritið Eldklerkurinn eftir Pétur Eggerz sem ég bæði sá á sviði og hafði undir höndum eintak af og vísað er í á nokkrum stöðum og tekið orðrétt úr, til dæmis bréf séra Jóns á blaðsíðu 98. Um aðrar heimildir vísast í söguna sjálfa. ${ }^{52}$

Notkun heimildanna er annað dæmi um hversu sjálfslýsandi skáldsagan er, og viðaukinn er eitt dæmi um pað sem Genette kallar hliðartexta (e. paratext). Upplýsingar um forlög, bókarheiti, formáli, eftirmáli, efnisyfirlit, bókarkápa, neðanmálsgreinar eru önnur dæmi um hann. Í raun er pað sem

51 Einar Már Guðmundsson, „Ávarp við viðtöku Íslensku bókmenntaverðlaunanna“, Tímarit Máls og menningar 1/2016, bls. 115-118, hér bls. 117.

52 Einar Már Guðmundsson, Hundadagar, Reykjavík: Mál og menning, 2016. Búast má við pví að Einar Már hafi stuðst við fleiri heimildir en hann hefur nefnt, t.d. er viðurnefnið förgen mera-taglskeri (199) fengið úr níðkveðskap Finns Magnússonar, sjá Sveinn Einarsson, „Söguhetjan Jörgen Jürgensen“, Andvari 1/2009, bls. 81-94, par sem finna má fleiri heimildir og bókmenntaverk par sem Jörgen Jörgensen er aðalpersóna; níð Finns Magnússonar er að finna á bls. 82 í greininni. 
bætist við texta svo að peir textarnir verði bók kallað hliðartexti, ${ }^{53}$ en í sagnritunarsjálfsögum má oft finna hliðartexta sem vísar beint eða óbeint til frásagnarathafnarinnar og hann er til vitnis um „íhugun um samband texta og hliðartexta í skáldsögu sem stefnir að staðreyndalegri nákvæmni (e. factual accuracy)“, eins og svissneski fræðimaðurinn Philippe Carrard bendir á í grein um franskar sagnritunarsjálfsögur. ${ }^{54}$

Heimildanotkunin veldur pví að í skáldsögunni rísa upp ýmiss konar textatengsl, sem eru ýmist af sagnfræðilegum eða bókmenntalegum toga. Рað er pá ekki aðeins vitnað í sagnfræðileg rit, heldur líka önnur skáldverk:

varð hún [fiðlan] upphaf mikils fiðluleiks í marga ættliði eins og lesa má um í bókum Böðvars Guðmundssonar, Hibýli vindanna og Lifsins tré. (205)

Um dvöl séra Jóns í hellinum má lesa í Skáldsögu um fón eftir Ófeig Sigurðsson. Hún kom út árið 2010. (299)

Með pví að viðurkenna og afhjúpa textatengslin gefur sögumaður til kynna að sögurnar í Hundadögum séu bæði raunverulegar og skáldaðar. Skáldsagan setur sig bæði í sögulegt og bókmenntasögulegt samhengi, og persónurnar eru pannig bæði sögulegar og skáldsögulegar. Segja má pví að Hundadagar „setji sig inn í sögulega orðræðu, en neiti samt að afsala sér sjálfstæði sínu sem skáldskapur“, eins og Hutcheon segir um sagnritunarsjálfsögur, ${ }^{55}$ en mörkin á milli sagnfræðinnar og skáldskaparins verða sömuleiðis óljós, pví að hér er undirstrikað að sérhver texti flækir sig inn í alls konar textatengsl fremur en vísi beinlínis út til raunverulegs empírísks heims. Enda pótt sagnfræðirit séu venjulega talin skírskota til raunverulegs heims (úthverf skírskotun) en skáldskapur til skáldaðs eða tilbúins heims (innhverf skírskotun), véfengja sagnritunarsjálfsögur pessa skoðun með ýmsum textatengslum og setja textaleika sagnfræðirita ennfremur í forgrunn ${ }^{56}$ - og sögumaður og lesendur nálgast pá sögu sem sögð er í Hundadögum einmitt $i$ gegnum ,innhverfar" heimildir og texta.

53 Gérard Genette, Paratext: Thresholds of Interpretation, pýð. Jane E. Lewin, Cambridge: Cambridge University Press, 1997 [1987 á frönsku], bls. 1.

54 Philippe Carrard, „Historiographic Metafiction, French Style“, Style 2/2014, bls. 181-202, hér bls. 185.

55 Linda Hutcheon, A Poetics of Postmodernism, bls. 124. Á ensku segir, „situate themselves within historical discourse, while refusing to surrender their autonomy as fiction."

56 Sama rit, bls. 141-157. 
En sagnritunarsjálfsögur, rétt eins og póstmódernisminn sjálfur, neita pó ekki tilvist sögunnar, heldur framandgera tilurð hennar og pekkingu manna um hana. Hutcheon segir til dæmis:

[Foucault, Lyotard og fleiri fræðimenn hafa ýjað að pví að] hvers konar bekking geti aldrei komist undan pví að hafa samvinnu við einhverskonar meta-frásögn, við hugarsmíðir sem geri mönnum kleift að eigna sér „sannleika“, sama hversu tímabundinn [sá sannleikur er]. Рað sem peir bæta við engu að síður er að engin frásögn getur verið náttúruleg stór-frásögn: pað er engin náttúruleg stigskipun; einungis sú sem við búum til. ${ }^{57}$

Sögumaðurinn í Hundadögum íhugar líka oft mörk lygi og sannleika. Hann telur að á milli pessara tveggja fyrirbæra séu engin endanleg mörk, og að sannleikur sé stundum beinlínis samheiti orðsins lygi: „Pví betur sem við kynnumst sannleikanum pví lygilegri verður hann. Við hvert skref sem stigið er, alltaf minnkar bilið á milli sannleika og lygi, raunveruleika og skáldskapar“ (206). Hann spyr líka: „En hvað er satt og hver lýgur hverju að hverjum?“ (70). Handan við lygina leynast aðrar spurningar áleitnar: Hverskonar sannleikur er sagður og frá hvaða sjónarmiði er hann sannleikur? Sögumanni pykir erfitt að gera greinarmun á sannleika og lygi, en pað stafar af pví að sannleikur er aldrei einn og óskiptur heldur eru fremur til margvíslegir „sannleikar“ í fleirtölu. ${ }^{58}$

Í pessu samhengi kynnu lesendur Hundadaga að vera forvitnir um: Hvaða sannleika eða sannleikum vill Einar Már Guðmundsson miðla með pessari skáldsögu sem segir frá og tengir saman sögur af nokkrum raunverulegum sögulegum persónum? Peir kunna jafnframt að undrast að sögumaðurinn skuli tengja Jörgen Jörgensen, séra Jón Steingrímsson og Finn Magnússon saman, og sumum pykir jafnvel að sögunum af séra Jóni og Finni sé ofaukið

57 Sama rit, bls. 13. Á ensku segir, ,any knowledge cannot escape complicity with some meta-narrative, with the fictions that render possible any claim to "truth," however provisional. What they add, however, is that no narrative can be a natural "master" narrative: there are no natural hierarchies; there are only those we construct." Vert er að taka fram að með hugtakinu „meta-frásögn“ (e. meta-narrative) á Hutcheon við „stór-frásögn“ (e. master narrative). Um hina eiginlegu metafrásögn sjá nmgr. 40.

58 Sama rit, bls. 109. Sbr. líka „En sá sannleikur / sá mælikvarði / sá fjársjóður / er ekki Sannleikurinn Mælikvarðinn og Fjársjóðurinn“, Sigfús Daðason, Ljóð 1947-1996, Reykjavík: JPV útgáfa, 2008, bls. 53. Ljóðið birtist upphaflega í Höndum og orðum (1959). 
í ljósi pess hve athyglisverð saga Jörgens sé. ${ }^{59}$ Höfundurinn lýsir sjálfur tengslunum svo í viðtali við Skapta Hallgrímsson:

Pegar pú ert með pá tvo, Jörund og Jón, og Finn Magnússon að auki, er hægt að búa til ákveðnar tengingar. [...] Maður hefur heyrt sögur um pessa menn, hvern í sínu lagi, en pegar maður hugsar petta í samhengi kemur í ljós að Jörgen er priggja ára pegar Skaftáreldar hefjast og ekki líða nema tæp prjátíu par pangað til hann kemur hingað. Petta er stuttur tími í sögunni en ofboðslega mikið að gerast parna á milli; franska byltingin og Napóleonsstyrjaldirnar, nýlendustefnan, öll pessi verslun og viðskipti og styrjaldir. Og pað er alveg makalaust hvernig petta tengist í gegnum einn mann eins og Sir Joseph Banks sem er bæði í pví að „uppgötva“ Ástralíu með James Cook og kemur svo hingað og hittir séra Jón Steingrímsson. ${ }^{60}$

Í öðru viðtali, spurður um tengsl persónanna priggja, kemst Einar Már einkar skemmtilega að orði: „Peir bara mættu í söguna, eins og krakkar í skóla“, ${ }^{61}$ en hann talar líka um hinn andlega eða buglega pátt sem bindur pá saman. Pessar sögulegu persónur virðast pannig ekki tengjast eingöngu á landfreðilegu korti, heldur líka á hinu bugmyndafreðilega korti. En í hverju er pessi huglægi páttur fólginn?

Pegar séra Jón Steingrímsson skrifaði ævisögu sína árið 1784-1791 var upplýsingaöldin gengin í garð á Íslandi, en franska byltingin í nafni frelsis, jafuréttis og breðralags gaus upp árið 1789. Nýlenduhyggjan varð til í kjölfar upplýsingarinnar, en stórríkin teygðu sig til „heimsendanna“ Ástralíu, Tasmaníu og Íslands. Skipin sigldu um höfin og færðu varning milli hafna, en pað voru líka styrjaldir, svo að „[̈̈]ll verslun var í skötulíki“ (134). Pess vegna má segja að tíðarandinn - Zeitgeist - í Hundadögum sé upplýsingin, en hún leiðir pó fyrst og fremst í ljós óvissu og óreiðu.

Jörgen var hrifinn af hugmyndum um frelsi, en líf hans valt á tilviljunum og ringulreið - hann ætlaði að verða sjómaður en hann varð hermaður,

59 Sjá t.d. Ingvi Pór Kormáksson, „Í heimsreisu með Jörundi“ og Pórdís Edda Jóhannesdóttir, „Saga um sögur“, Hugrás.is, 2015, sótt 22. febrúar 2019 af http://hugras.is/2015/11/saga-um-sogur/.

60 Skapti Hallgrímsson, „Erum alltaf stödd í einhverri sögu“, Morgunblaðið sunnudagur 13. desember 2015, bls. 54-55, hér bls. 54 .

61 Viðtal við Einar Má í pættinum Bók vikunnar á Rás 1, 29. maí 2016, Rúv.is, sótt 22. febrúar 2019 af http://www.ruv.is/frett/hundadagar-einar-mar-gudmundsson. 
hann ætlaði að vera kaupmaður á Íslandi en varð loks byltingarmaður. Hann verndaði föðurland sitt í stríði Dana við Breta, en var ákærður fyrir landráð. Hann steypti Dananum Trampe greifa af stóli og ruddi Bretum braut að hertaka Ísland, en Bretar vildu fremur hlusta á Trampe og vísuðu Jörgen úr landi. „[T]alið var að Jörgen Jörgensen gengi jafnvel lengra en hinir byltingarsinnuðu Frakkar“ (195) og samkvæmt peirri túlkun var Jörgen mesti og róttækasti demókrati nítjándu aldarinnar, en bylting hans misheppnaðist samt - sá upplýsingarandi sem Jörgen hafði að leiðarljósi brást, af pví að „[p]egar Napóleonsstríðum lauk nokkrum árum síðar gátu Danir hert tök sín á Íslandi að nýju sökum pess hve sáttfúsir Bretar voru við pá enda búnir að fara illa með pá, [...] en eftir pví sem leið á öldina, pá nítjándu, jókst krafan um frjálsa verslun og gekk að lokum eftir“ (214), segir sögumaður, en hann lýsir líka nákvæmlega hvernig hin verklega skynsemi (e. instrumental reason) leysti upplýsingaskynsemi af hólmi ${ }^{62}$ - ef upplýsingarhugsjónir gátu ekki stuðlað að efnahagslegri próun eða verið gagnleg verkfæri kapítalismans urðu pær býðingarlausar.

Í sögum séra Jóns er hugtakið réttlæti sett á oddinn. Hann rauf innsigli landstjórans í peningatökumálinu svokallaða sem tengdist Skaftáreldunum ${ }^{63}$ og dreifði styrk frá danska kónginum til peirra „sem purftu á honum að halda í stað pess að fara með hann innsiglaðan í kistli sínum til Lýðs Guðmundssonar sýslumanns svo hann gæti virt hann fyrir sér, handleikið hann og velt vöngum yfir pví hvað hann ætlaði að gera við peningana sem í kistlinum voru“ (222). Hann póttist vera að koma réttlæti í framkvæmd en málinu lauk með pví að hann purfti að borga sekt. Рað sem Finnur Magnússon sóttist eftir - pekkingin - varð honum líka að falli. Hann hélt að rétt væri að lesa rúnir í Blekinge sem hann hafði verið að rannsaka frá hægri til vinstri, og hélt mikið upp á pessa glæsilegu uppgötvun sína og stærsta daginn í lífi sínu sem fræðimanns, en allt reyndist vera sjónhverfing. Sögupersónurnar Jörgen, séra Jón og Finnur voru sannarlega í takti við pann tíma sem pær hrærðust í, en að vissu leyti voru pær einnig strengjabrúður og jafnvel fórnarlömb tíðarandans. Frá pessum sjónarhóli fá allar aðalpersónurnar í Hundadögum hlutverk utan stórsögunnar og fara úr skorðum hennar, svo ekki dugi að túlka ævi peirra eingöngu út frá leiðarfrásögn upplýsingarinnar. Pannig er

62 Sbr. Max Horkheimer og Theodor W. Adorno, Dialectic of Enlightenment: Philosophical Fragments, býð. Edmund Jephcott, Stanford: Stanford University Press, 2002 [1944, 1947 á pýsku].

63 Séra Jón tók „fé úr hjálparsjóði án heimildar vegna Skaftáreldanna“, sjá Matthías V. Sæmundsson, „Upplýsingaröld 1750-1840“, bls. 125. 
ekki til einn sögulegur sannleikur sem getur nýst sem meta-sannleikur til að útskýra allt, heldur býr sagan yfir margvíslegum sannleikum. Par sem upplýsingin bregst, rís avintýri og rómantík upp, ${ }^{64}$ og (skáld)sagan, eins og sögumaður kemst að orði, er pá „bæði sprellfjörug, skrautleg og skemmtileg en dettur stundum niður í depurð og punglyndi og hjakkar í sama farinu árum og jafnvel öldum saman“ (17).

„Sagan fer fram og aftur blindgötuna, upp og niður dagatalið og endurtekur sig“ (26) er niðurstaðan sem sögumaður kemst að pegar hann leiðir hugann að samtíma sínum. Honum pykir eins og fortíðin og samtíminn kallist á pegar hann ber saman búsáhaldabyltinguna 2009 í kjölfar íslenska hrunsins og hina misheppnuðu byltingu Jörgens 1809: „Tvö hundruð árum seinna endurtók nákvæmlega sama sagan sig nema pá var pað ekki Alexander Jones skipstjóri heldur forsætisráðherra landsins sem kallaði allan almenning í búsáhaldabyltingunni skríl skömmu eftir að hann bað guð um að blessa landið“ (204).

Stjórnvöldin fyrr og nú hafa sama orðið (skríl) um almenning sem tekur pátt í byltingu, en staða Íslands nú er heldur ekki ýkja ósvipuð peirri sem blasti við á 19. öld pegar Ísland var nýlenda Danmerkur, ${ }^{65}$ að minnsta kosti ef hugsað er til pess að í augum annarra - einkum túrista - er Ísland enn holdgerving hins frumstæða. En núna er í raun um að ræða meðvitað val og aðferð til að kynna landið, eins og sjá má í kynningarmyndbandinu Inspired by Iceland: „Og einhvers staðar parna inni í myndinni erum við, skringilegt háttalag okkar og hegðun, og við reynum að standa undir væntingum sem göfugir villimenn, hnattvæddir frummenn og jafnvel bobbitar" (103). Ljósi er pannig varpað á hina póstkólónísku stöðu Íslands í heiminum og gefið er í skyn að nýlenduhyggja sé ennpá til í dag en hafi skipt hömum: hún snúist nú ekki endilega um utanaðkomandi og opinbera kúgun, heldur frekar einskonar sjálfs-nýlendun, einskonar samseri eða međvirkni í págu efnahagslegs hagnaðar. ${ }^{66}$

${ }^{64}$ Sbr. káputexta Hundadaga: „Og sagan er ævintýraleg - og ævintýrin söguleg““.

65 Sjá t.d. Jón Yngvi Jóhannsson, „Scandinavian Orientalism: The Reception of Danish-Icelandic Literature 1905-1950“, Nordisk litteratur og mentalitet, ritstj. Malan Marnersdóttir og Jens Cramer, Tórshavn: Fróðskaparfelag, 2000, bls. 254-261.

66 Sjá Morten Jest, „Virkeligheden overgår fantasien“, Gymnasieskolen.dk, 9. nóvember 2015, sótt 25. febrúar 2019 af https://gymnasieskolen.dk/virkeligheden-overgaarfantasien: „Hundedage beskriver ikke alene koloniale strukturer og kampe et par århundreder tilbage, men trækker også tråde til nutiden, hvor de koloniale ideologier ifølge Guðmundsson lever videre på en række områder. For eksempel i forhold til turisme, hvor vi udstiller vores kultur som forventet og opfører os, som det for- 
Spyrja má hvaða líkindi önnur sögumaður bendi á milli tímaskeiðanna tveggja. Var hrunið 2008 Skaftáreldar nútímans sem eyðilögðu peninga og eigur manna? ${ }^{67}$ Voru Bretar aftur inspired by Iceland eins og Joseph Banks á sínum tíma (204)? Eiga kapítalismi 19. aldar og 21. aldar eitthvað sameiginlegt? Var hrunið déjà vu pess sem gerðist í fortíðinni? Eða var veruleiki hrunsins pegar innifalinn í sögunni? Tvennir sögulegir tímar kallast innbyrðis á með peim allegóríska hætti sem Paul de Man skilgreinir: merkingarmyndun allegóríunnar á sér stað í endurtekningu fremur en samsvörun, í krafti pess að allegórían vísar einatt til pess sem til er á undan henni; hún býr yfir fjarlægð frá uppruna sínum, neitar að samrýmast nokkurri sögn frá gömlum tíma - merking allegóríunnar verður einmitt til í mismuninum á tvennum tímaskeiðum, í misgengi tímans. ${ }^{68}$ Pannig er virkni allegóríunnar, en pannig er líka saga okkar, sem endurtekur sig en birtist pó alltaf í öðruvísi ham í tímanna rás. Sagan er pví í vissum skilningi eins og vof $a^{69}$ sem neitar að hafa sig á brott; hún „kemur okkur alltaf í opna skjöldu“ (21), en sviptir sífellt hulunni af sjálfri sér í endurtekningum með tilbreytingum. Og pess vegna er býðingarmikið að vitja sögunnar aftur og aftur og skrifa um söguna, ígrunda tilvist hennar og pekkingu okkar á henni. Pað er pá pessi boðskapur sem Einar Már Guðmundsson vill miðla til okkar með sagnritunarsjálfsögunni Hundadögum: sagan skiptir býsna miklu máli og „[v]ið sem segjum svona sögur og rifjum pær upp til að minna á hið gleymda erum pví á bandi guðs“ (39).

ventes. Perioder, vi tror er afsluttet, er ikke altid afsluttet. Det samme gælder det dansk-islandske forhold [...].“

67 Sjá líka Einar Már Jónsson, „Örlögsímu“, Tímarit Máls og menningar 4/2016, bls. 136-139, hér bls. 139.

68 Paul de Man, "The Rhetoric of Temporality“, Blindness and Insight: Essays in the Rhetoric of Contemporary Criticism, 2. útg., Minneapolis: University of Minnesota Press, 1983, bls. 187-228, hér bls. 207. Á ensku segir, „the allegorical sign refer to another sign that precedes it. The meaning constituted by the allegorical sign can then consist only in the repetition [...] of a previous sign with which it can never coincide, since it is of the essence of this previous sign to be pure anteriority. [...] allegory designates primarily a distance in relation to its own origin, and, renouncing the nostalgia and the desire to coincide, it establishes its language in the void of this temporal difference. In so doing, it prevents the self from an illusory identification with the non-self, which is now fully, though painfully, recognized as a non-self."

69 Jacques Derrida, Specters of Marx: The State of the Debt, the Work of Mourning and the New International, pýð. Peggy Kamuf, New York and London: Routledge, 1994 [1993 á frönsku]. Sbr. líka einkunnarorð Hundadaga: „History has many cunning passages ..." - T. S. Eliot, Gerontion. 


\section{Að lokum}

Sagnritunarsjálfsaga hefur reynst nytsamlegt hugtak til greiningar á póstmódernískum skáldsögum, en kenningar Hutcheon hafa einnig sætt gagnrýni. Hún gefur oftar en ekki í skyn að sagnritunarsjálfsögur séu eina ósvikna birtingarform póstmódernískra skáldsagna en ýmsir hafa bent á að málflutningur hennar um pað efni byggist á of miklum alhæfingum. ${ }^{70}$ Auðvitað eru til fleiri tegundir af póstmódernískum skáldsögum en sagnritunarsjálfsögur, og pað má einnig skipta sagnritunarsjálfsögum í ýmsar undirgreinar. Pýski frásagnarfræðingurinn Ansgar Nünning gerir einmitt tilraun til pess í sínum skrifum. Hann telur að til séu annars vegar opinskáar (e. explicit) og hins vegar duldar (e. implicit) sagnritunarsjálfsögur. Í peim fyrrnefndu er fjallað opinskátt um pau pekkingarfræðilegu, aðferðafræðilegu og málvísindalegu vandamál sem tengjast uppbyggingu sögunnar á sjálfsögulegan hátt, og pá birtist líka sterk sjálfsvitund. Í duldum sagnritunarsjálfsögum gerir sjálfsvitundin sjaldnast vart við sig; pað sem leiðir vandamálin í ljós er fyrst og fremst innri uppbygging og frásagnartækni skáldsögunnar. Höfundar setja til dæmis fram hlið við hlið mótsagnakenndar frásagnir og mismunandi túlkanir á sama atburði. ${ }^{71}$ Nünning kynnir líka tvær aðrar gerðir af póstmódernískum sögulegum skáldskap en pær eru endurskoðandi sögulegar skáldsögur (e. revisionist historical novels) par sem stefnt er að pví að endursemja sögu, og metasögulegar skáldsögur (e. metahistorical novels) par sem nútímamaður skoðar, túlkar og skrifar um fortíðina út frá nútímalegu sjónarhorni. ${ }^{72}$ Hugtakið sagnritunarsjálfsögur hefur nýst best til að lýsa sögulegum skáldskap frá 6. og 7. áratugnum á síðustu öld, en Amy J. Elias kynnir til sögunnar hugtakið metasöguleg rómansa (e. metahistorical romance) í skrifum sínum um sögulegan skáldskap eftir pað. ${ }^{73}$ Stungið hefur verið upp á öðrum hugtökum til að lýsa nýlegri próun í sögulegum skáldskap, til dæmis póst-bugsmiðabyggju-metasagnritunar-skáldskap (e. post-constructivist metahistoriographic fic-

70 Brian McHale, „Postmodernism, or The Anxiety of Master Narratives“, Diacritics 1/1992, bls. 17-33; Monika Fludernik, „History and metafiction“; Gunnpórunn Guðmundsdóttir, „Skáldað um líf“; Ansgar Nünning, „Where Historiographic Metafiction and Narratology Meet: Towards an Applied Cultural Narratology", Style 3/2004, bls. 352-375.

71 Sama rit, bls. 365-369.

72 Sama rit, bls. 362-365. Hugtakið endurskoðandi sögulegar skáldsögur fær Nünning raunar lánað hjá Brian McHale, sjá nmgr. 43.

73 Sjá Amy J. Elias, Sublime Desire; „Historiographic metafiction“, bls. 303-305. 
tion $)^{74}$ og ný-sögulegum skáldskap (e. neo-bistorical fiction), ${ }^{75}$ en ekkert peirra hugtaka hefur haft jafnmikil áhrif og hugtak Hutcheon.

Sjálfur er ég á peirri skoðun að hægt sé að nýta hugtakið sagnritunarsjálfsaga til að lýsa peim tilraunakenndu bókmenntaverkum, eins og Hundadögum, sem eru upptekin af sögulegum efnum og einkennast af sjálfsvitund um riteðli sögunnar; mögulegt er pá að nálgast sögu í formi skáldskapar. Slík sampætting sögu og skáldskapar, veruleika og ævintýris, raunsæis og rómantíkur, hefur einmitt lengi verið einn kjarninn í fagurfræði Einars Más Guðmundssonar. ${ }^{76}$ Frásagnargleðin er ætíð afar mikil og leiftrandi í skáldsögum hans, og hann lítur eiginlega á allt sem hugsanleg efni fyrir skáldsögur, eins og skýrt kemur fram í skrifum hans um petta efni: „Рað sem skynsemishyggjan lítur á sem tvo aðgreinda póla sér skáldskapurinn sem eina heild, ævintýrið og veruleikann í einni sæng. Andinn er ekki aðeins afurð heimsins, heldur skapar hann jafnframt pennan sama heim. Draumar og hugsanir eru líka veruleiki." ${ }^{\text {"77 }}$ Рað er pví engin furða að saga og skáldskapur, veruleiki og ævintýri renni saman í Hundadögum. Einar Már glímir við söguna með pví að segja sögur, enda er hann rithöfundur. En við lesendur komum til móts við söguna og sögurnar pegar við lesum, hlustum á pær, og skynjum pær með líkama og huga. Er petta allt ekki prýðilegur vitnisburður um eilífa pörf mannsandans fyrir frásagnir - og fyrir sögu? „Seg mér Sönggyðja ...“, segir Hómer (70). Petta bergmál úr fortíðinni kveður enn og aftur við í nútíma okkar.

74 Manja Kürschner, "The Fictionalization of History in Metahistoriographic Fiction after the Constructivist Challenge“, Emerging Vectors of Narratology, ritstj. Per Krogh Hansen, John Pier, Philippe Roussin og Wolf Schmid, Berlín og Boston: de Gruyter, 2017, bls. 153-170.

75 Ann Heilmann og Mark Llewellyn, Neo-Victorianism: The Victorians in the TwentyFirst Century, 1999-2009, London: Palgrave/MacMillan, 2010. Sjá Bergljót Soffía Kristjánsdóttir, ,„Mannkynssagan sem söguleg skáldsaga“: Vangaveltur um sögulegan skáldskap og framgang hans hérlendis á pessari öld“, Tímarit Máls og menningar 3/2018, bls. 85-97.

76 Sjá Guðni Elísson, „Heimurinn sem krónísk ranghugmynd: Átök undurs og raunsæis í verkum Einars Más Guðmundssonar“, Skírnir 171: vor/1997, bls. 165-196.

77 Einar Már Guðmundsson, „Hin raunsæja ímyndun“, Tímarit Máls og menningar 2/1990, bls. 97-104, hér bls. 100. 


\section{ÚT D RÁTT U R \\ „Pannig er saga okkar“ \\ Um sagnritunarsjálfsögur og skáldsöguna Hundadaga eftir Einar Má Guðmundsson}

Í skáldsögunni Hundadögum (2015) eftir Einar Má Guðmundsson vofir hin áleitna spurning hvernig samband milli veruleika og skáldskapar sé yfir, enda er um að ræða skáldskap um rannverulegar sögulegar persónur og atburði (Jörgen Jörgensen, séra Jón Steingrímsson, Finn Magnússon, Guðrúnu Johnsen o.fl.), en pað sama má segja um allmargar aðrar skáldsögur sem kenndar eru við póstmódernisma. Kanadíski bókmenntafræðingurinn Linda Hutcheon nefnir slík skáldverk sagnritunarsjálfsögur eða historiographic metafiction: skáldverk sem eru „sjálfslýsandi en leggja hald sitt á sögulega atburði og persónur á pverstæðukenndan hátt". Að mati Hutcheon sýna sagnritunarsjálfsögur hvað best hvernig póstmódernismi er upptekinn af bæði pekkingarfræðilegri og verufræðilegri stöðu sögunnar. Í greininni er fyrst drepið á kenningar Hutcheon um póstmódernisma, póstmódernískan skáldskap og samband milli sögu og skáldskapar, en pá er skáldsagan Hundadagar greind ítarlega með hliðsjón af hugtakinu sagnritunarsjálfsaga. Rýnt er í frásagnaraðferðir sögumanns, svo sem samskipan/hliðskipan, metafrásagnarlegar athugasemdir, „við“-frásagnarorðræðu og heimildanotkun, sem segja má að í vissum skilningi séu eftirlíking, afhjúpun og paródía á pví ferli sem búi að baki sagnfræðilegum ritum. Pví er haldið fram að endurskoðun sögumanns Hundadaga á 18. og 19. öldinni eigi rætur að rekja til bankahrunsins 2008 á Íslandi pegar upplýsingargildin brugðust og leiddu til óreiðu og óvissu. Meira að segja hefur sögumaður fundið ókennileg líkindi milli fortíðarinnar og nútímans, eins og sagan hafi endurtekið sig. Í misgengi tímans birtist pá vofa sögunnar og með pví að endurvitja fortíðarinnar nálgast sögumaður Hundadaga nútímann á allegórískan hátt. Sem sagnritunarsjálfsaga er skáldsagan Hundadagar pannig „mótsagnakennd, eindregið söguleg og óhjákvæmilega pólitísk“, rétt eins og póstmódernisminn sjálfur að viti Hutcheon.

Lykilorð: Póstmódernismi, póstmódernískar bókmenntir, sagnritunarsjálfsaga, Einar Már Guðmundsson, Hundadagar, íslenska efnahagshrunið, saga og skáldskapur 


\section{A B S T R A C T \\ „So is our (hi)story“ \\ On historiographic metafiction and Einar Már Guðmundsson's Hundadagar}

The ambiguity between reality and fiction haunts Einar Már Guðmundsson's novel Hundadagar (Dog Days, 2015), as it is a fictional narrative about factual, historical figures and events, such as Jörgen Jörgensen, Rev. Jón Steingrímsson, Finnur Magnússon and Guðrún Johnsen, while the same can be said about many other novels labeled as postmodernism. Canadian literary scholar Linda Hutcheon coined the concept of historiographic metafiction to describe fictions as such, which are "intensely self-reflexive", while "paradoxically lay claim to historical events and personages". Hutcheon suggests that historiographic metafictions fully illuminate the very way in which postmodernism entangles itself with both the epistemological and ontological status of history. This paper begins with an introduction to Hutcheon's theoretical contributions on postmodernism, postmodern literature and the relationship between history and fiction, followed by a reading of Hundadagar as a historiographic metafiction. The narrator's strategies-such as parataxis, metanarrative comments, we-narrative discourse and documentary intertext-largely indicate an imitation, a revelation, or say, a parody of the process of historian's writings. The paper further suggests that it is the Icelandic financial crisis in 2008 that prompts the narrator to revisit the 18. and 19. century, since the financial crisis takes the role of a rupture of the Enlightenment ideals, leading to disorder and chaos. Moreover, the narrator finds an uncanny similarity between the past and the present, as if the history has been repeating itself. The spectre of history keeps (re)appearing in a deferred temporality. While revisiting the past, the narrator also (re)visits the present in an allegorical way. In a word, as a historiographic metafiction, Einar Már Guðmundsson’s Hundadagar is "fundamentally contradictory, resolutely historical, and inescapably political”, just as Hutcheon's perception of postmodernism.

Keyzwords: Postmodernism, postmodern literature, historiographic metafiction, Einar Már Guðmundsson, Hundadagar, the Icelandic financial crisis, history and fiction

\section{XINYU ZHANG}

Meistaranemi í íslenskum bókmenntum

Íslensku- og menningardeild

Hugvísindasviði Háskóla Íslands

Sæmundargötu 2

IS-101 Reykjavík, Ísland

xiz3@hi.is 
